\title{
Analisis Risiko dalam Investasi Islam
}

Nafis Irkhami

Sekolah Tinggi Agama Islam Negeri Salatiga

nafis_ir@yahoo.com

\begin{abstract}
:
Business activities and investments could not be separated from risk, because the return was a result of the risk analysis. Based on its nature, it was no small investment activities, especially in the field of financial assets, which in fact exploit the conditions in a way to speculate. In many cases, these speculators caused often create economic inequality, even crisis. This article would find footing construction investment ethical analysis of Islamic pespectives, including the instruments of the screening process, as well as the concept of Islamic investment analysis of risk and return.
\end{abstract}

Keywords: Islamic ethical investment, investment analysis, risk

\section{Pendahuluan}

Kata investasi merupakan kata adopsi dari bahasa Inggris, yaitu investment. Kata invest sebagai kata dasar dari investment memiliki arti menanam. Secara sederhana, investasi dapat diartikan sebagai suatu kegiatan menanam harta yang bertujuan untuk mengembangkannya. Secara lebih praktis, investasi merupakan suatu komitmen atas sejumlah dana atau sumber daya lainnya yang dilakukan pada saat sekarang dengan harapan memperoleh sejumlah keuntungan di masa yang akan datang (Tandelilin, 2001). Berdasarkan pengertian tersebut dapat dipahami bila investasi merupakan suatu kegiatan ekonomi yang tidak dapat dipisahkan dengan kehidupan homo economicus.

Kegiatan pengembangan atau penanaman harta mensyaratkan adanya komitmen untuk mengorbankan sejumlah dana tertentu saat ini dengan harapan memperoleh sejumlah keuntungan di masa datang (Jones, 1996: 6). Keuntungan yang diharapkan tersebut tentu tidak dapat dipastikan 
besarnya, bahkan bisa jadi investor mengalami kerugian atau kehilangan dananya. Dengan kata lain, seorang investor akan selalu berhubungan dengan risiko ketidakpastian bisnis di masa yang akan datang.

Untuk mencapai sasaran memaksimumkan pengembalian investasi, seorang investor harus melakukan analisis terhadap dua faktor penentu utama, yaitu tingkat risiko dan tingkat pengembalian. Setiap keputusan keuangan mengandung unsur risiko dan pengembalian yang berbeda-beda. Selanjutnya, setiap keputusan investasi harus memperhatikan tingkat pengembalian dari berbagai tingkat risiko tersebut.

Pada umumnya investasi dibedakan menjadi dua, yaitu investasi pada financial asset dan investasi pada real asset. Investasi financial asset dilakukan di pasar uang, misalnya berupa sertifikat deposito, commercial paper, Surat Berharga Pasar Uang (SBPU), dan lain sebagainya. Investasi ini juga dapat dilakukan di pasar modal, misalnya berupa saham, obligasi, warrant, opsi, dan sebagainya. Sedangkan investasi pada real asset dapat dilakukan dengan pembelian aset produktif, pendirian pabrik, pembukaan pertambangan, perkebunan, dan sebagainya. Untuk selanjutnya, investasi dalam tulisan ini dimaksudkan sebagai financial assets.

Berbagai macam kegiatan investasi tersebut di atas pada umumnya memiliki tujuan yang sama, profitabilitas atau penghasilan (return). Untuk sampai pada tujuan akhir yang diharapkan, seorang investor harus mengambil keputusan yang tepat untuk memilih objek serta mempertimbangkan waktu dan kondisi. Pada umumnya hubungan antara risiko (risk) dan tingkat pengembalian yang diharapkan (expected rate of return) bersifat linier. Artinya, semakin tinggi tingkat risiko, maka semakin tinggi pula tingkat pengembalian yang diharapkan. Setelah menetapkan tujuan, langkah selanjutnya adalah melakukan analisis terhadap suatu efek atau beberapa efek. Salah satu tujuan dari penilaian ini adalah untuk melakukan identifikasi harga suatu efek.

Penilaian keberhasilan investasi tidak saja ditentukan oleh tingkat pengembalian yang tinggi sebagaimana terkonsep dalam ekonomi konvensional. Dewasa ini kecenderungan motivasi berinvestasi mulai mengalami pergeseran, di mana investasi tidak saja dipandang sebagai kegiatan yang memberikan kepuasan finansial atau tingkat pengembalian yang tinggi, 
namun juga kepuasan spiritual. Kecenderungan investasi semacam ini disebut sebagai ethical investment, yakni investasi yang dapat dipertanggungjawabkan secara sosial, karena menggunakan pertimbangan etika (ethical screening).

Unsur spekulasi dalam perilaku investasi konvensional diyakini oleh banyak kalangan dapat memberikan kontribusi bagi berbagai krisis perekonomian dunia. Sebagai contoh, great depression pada tahun 1930-an diawali dengan spekulasi besar-besaran di Wall Street. Selain itu, devaluasi Poundsterling pada tahun 1967 dan krisis mata uang Frank pada tahun 1969. Terakhir devaluasi Bath Thailand menyebabkan penarikan investasi besarbesaran di pasar modal yang kemudian menimbulkan krisis ekonomi. Halhal tersebut, menurut Esta, membawa kesadaran bagi investor akan pentingnya investasi yang lebih etis (Lestari, 2008: 171).

Filosofi perilaku investasi ekonomi konvesional yang pada mulanya lebih dituntun oleh kekuatan pasar, memiliki perbedaan mendasar dengan filosofi ethical investment yang lebih mengedepankan etika. Pilihan-pilihan serta bentuk-bentuk penilaian investasi seharusnya tidak hanya didasarkan kepada dua pertimbangan pokok; risiko dan pengembalian (keuntungan finansial), namun juga karakteristik dari perusahaan yang diinvestasikan. Hal ini meliputi bentuk barang dan jasa yang diproduksi, lokasi bisnis dan cara bagaimana kegiatan perusahaan dioperasikan (Wilson: 1325). Secara umum, kriteria ethical investment dapat dikategorikan menjadi dua; positif dan negatif. Kriteria positif dimaksudkan sebagai kegiatan investasi yang ramah atau peduli lingkungan. Sedangkan investasi etis yang negatif dimaksudkan bahwa perusahaan tidak bergerak dalam industri atau sektor yang tidak diperbolehkan secara moral, seperti minuman keras, tembakau, perjudian, atau pornografi.

Konsep ethical investment versi Barat dengan Islamic (ethical) investment tentu memiliki epistemologi yang berbeda. Meskipun demikian, keduanya memiliki domain yang "berarsiran." Dalam hal ini, secara normatifdoktrinal, Islam telah lebih dahulu mengembangkan konsep muamalah yang tidak hanya berbasis keuntungan materi, namun juga immateriil. Di samping itu, fikih tentang lingkungan (ekologi) dan fikih ekonomi-sosial (ekososial) juga telah menjadi pembahasan sejak awal. Hanya saja, harus diakui bahwa 
dunia Islam masih tertinggal jauh dalam tataran praktis.

Berangkat dari latar belakang tersebut di atas, maka persoalanpersoalan Islamic ethical investment yang menjadi pembahasan makalah ini adalah mengenai konstruksi analisis ethical investment perspektif Islam, instrumen yang digunakan sebagai pertimbangan dalam proses screening investasi, serta mengenai konsep analisis investasi Islami terhadap risiko dan pengembalian.

\section{Islamic Ethical Investments Screening}

Pengembangan kinerja pasar modal syariah diawali dengan analisis kinerja investasi yang sesuai dengan etika (ethical investment) yang marak sejak tahun 1970-an (Wilson: 1325). Konsep ethical investment pada awalnya datang dari negara-negara Barat yang mengembangkan investasi khusus bagi konsumen atau investor yang sangat spesifik, di mana mereka sangat peduli pada bentuk investasi yang dapat dipertanggungjawabkan secara sosial. Cowton mendefinisikannya dengan "...the use of ethical and social criteria in the selection and management of investment portofolio, generally consisting of company shares" (Prindl, 1994: 213). Dengan kata lain, investasi ini telah melalui seleksi aturan tertentu, baik moral maupun ekonomis.

Islamic ethical investment merupakan bagian dari kegiatan investasi yang mempertimbangkan nilai-nilai etika dan agama. Sebagaimana ethical investment, investasi ini ditujukan untuk memenuhi kebutuhan kelompok investor yang menginginkan memperoleh pendapatan investasi dari sumber dan cara yang bersih yang dapat dipertanggungjawabkan secara religius (syar'iy). Dengan demikian, pemenuhan nilai-nilai syariah menjadi tujuan utama.

Perbedaan pokok Islamic ethical investment dengan investasi konvensional adalah dalam operasionalnya, dan yang paling mendasar adalah pada proses screening dalam mengkonstruksi portofolio. Filterisasi berdasarkan syariah ini mencakup aspek kualitatif dan kuantitatif. Screening pada aspek kualitatif meliputi penilaian terhadap content assets; 1) apakah perusahaan bergerak dalam sektor yang dilarang atau tidak; 2) apakah dalam prakteknya menggunakan unsur-unsur riba; 3) apakah prakteknya me- 
ngandung maysir dan gharar. Proses ini akan menyingkirkan berbagai saham yang memiliki aktifitas haram seperti riba, gharar, minuman keras, judi, daging babi, rokok dan seterusnya.

Screening pada aspek kuantitatif mempertimbangkan hal-hal seperti debt and equity ratio dan valuasi atas hasil appraisal bisnis yang bersangkutan (Lestari, 2008: 175). Selain kedua proses screening tersebut, proses filterisasi dengan Islamic ethical investment masih dilanjutkan dengan pemenuhan kewajiban moralitas lainnya seperti charity.

Islamic ethical investment seringkali disejajarkan dengan Social Responsible Investment (SRI). Tujuan utama dari kegiatan yang diklaim sebagai bisnis etis ini adalah gabungan antara keuntungan dan moralitas. Umumnya SRI berkaitan dengan saham di perusahaan. Secara tradisional, fund manager akan memilih saham-saham murni berdasarkan atas kinerja keuangan perusahaan. Namun akhir-akhir ini, mereka mulai memasukkan pertimbangan lingkungan dan sosial dalam putusan-putusan investasinya.

Minat publik terhadap SRI berkembang sejalan dengan meningkatnya kewaspadaan terhadap dampak aktivitas ekonomi terhadap masyarakat dan lingkungannya. Keberlangsungan atau keberlanjutan usaha yang dulu merupakan pertimbangan utama bagi suatu praktik bisnis untuk disebut sebagai bisnis yang berhasil (good business practice), sekarang telah mengalami pergeseran.

Perkembangan pesat dari SRI menimbulkan pertanyaan, mengapa socially responsible management funds ini memiliki peluang besar? Studi yang dilakukan Jusmaliani (2008: 68) mengemukakan berbagai jawaban, di antaranya adalah sebagai berikut:

1. Dengan mengurangi output energi dan buangan, misalnya, perusahaan akan terhindar dari berbagai jenis pajak baru seperti pajak landfill, pajak berkaitan dengan karbon dan pajak perubahan iklim dan seterusnya. Dengan demikian langkah tersebut justru akan mengurangi biaya pengeluaran.

2. Menghindari risiko yang buruk. Perusahaan-perusahaan yang dikeluarkan dari dana SRI akan menghadapi berbagai persoalan di masa yang akan datang. Penilaian masyarakat akan memaksa mereka tersingkir dari kompetisi pasar. 
3. Penguasaan terhadap isu-isu lingkungan dan sosial memberi potensi pertumbuhan modal yang masif.

Meskipun SRI mengalami perkembangan pesat, namun tidak semua kalangan memberikan sambutan positif. Bahkan Milton Friedman, seorang pemenang nobel 1962 menyatakan bahwa satu-satunya tanggung jawab sosial adalah untuk menggunakan sumber daya yang ada sebaik-baiknya dalam rangka maksimasi keuntungan (Shaw and Berry, 1995: 207). Dalam bidang investasi, contoh penolakan dilakukan oleh kelompok Investment$U$. Pandangan umum dari kelompok ini, mengikuti Friedman, adalah bahwa tujuan penanaman investasi di perusahaan adalah untuk memperoleh keuntungan, bukan untuk menyelamatkan dunia. Mereka mengemukakan penelitian-penelitian kuantitatif, seperti yang dilakukan Wharton School (2003), yang menyimpulkan bahwa para investor SRI menderita kerugian 3,5 persen poin pertahun. Selanjutnya, bila dibandingkan dengan investor non-SRI, mereka tertinggal 18 persen. Dari sisi performa, penelitian Hajara Atta (2000) juga membuktikan bahwa ethical screening akan menurunkan performa investasi. Disertasi Atta yang meneliti pengaruh ethical screening (Islamic investment) terhadap performance investasi di Dow Jones Islamic Market dan FTSE Global Islamic ini menyimpulkan bahwa dengan ethical investment screening, kinerja DJIM dan FTSE GI menjadi abnormal.

Kesimpulan dari penelitian Wharton dan Atta tersebut (dan berbagai penelitian serupa lainnya) dalam Schroeder (1995) mestinya bisa dipahami mengingat orientasi bisnis (investasi) dari ethical investment tidak hanya pada aspek profit semata, namun juga mempertimbangkan moral, sehingga perusahaan harus memilih content assets tertentu saja dan di samping itu juga harus menyediakan pengeluaran lebih tinggi untuk sektor sosial. Di sisi lain, penelitian-penelitian yang membuktikan tidak adanya pengaruh screening etis dalam investasi, baik pada kinerjanya maupun pada return dan risikonya, juga telah banyak dilakukan. Di antaranya adalah penelitian yang dilakukan bersama-sama oleh Abul Hassan, Antonios Antoniu dan D. Krishna Paudyal (2005) yang menyimpulkan bahwa penerapan ethical investment (Islam), tidak berpengaruh terhadap performa investasi di DJIM.

Pada sisi ekstrim lain, studi dan penelitian yang mengungkap "prospek cerah" maupun "keunggulan" Islamic ethical investment dari berbagai 
sisi juga tidak sedikit dilakukan. Termasuk dalam hal ini adalah penelitian yang menganalisis maupun mengkomparasikan kinerja pasar modal syariah dengan konvensional (non-ethical). Pada umumnya studi tersebut dilakukan oleh para ekonom muslim. Di Indonesia, penelitian yang termasuk dalam kategori terakhir ini, dilakukan oleh Rahmayanti dalam Huda dan Mustafa (2007: 67-70) yang menyimpulkan bahwa saham syariah yang tergabung dalam Jakarta Islamic Index secara umum memiliki kinerja yang lebih baik dibanding konvensional. Demikian juga penelitian Abu Bakar dan Rizal (2007). Penelitian komparatif Huda menunjukkan bahwa risiko di JII berada di bawah risiko pasar, sebaliknya dengan yang terjadi pada saham konvensional dalam Huda dan Mustafa (2007: 70-71)

\section{Risiko dan Pengembalian dalam Investasi}

Tujuan investasi adalah memperoleh tingkat pengembalian tertentu (pada umumnya setinggi mungkin) dengan sumber daya tertentu. Dalam ekonomi konvensional, setidaknya ada tiga hal yang perlu dipertimbangkan seorang investor dalam menanamkan modalnya, yaitu: 1) tingkat pengembalian yang diharapkan (expected return), 2) tingkat risiko (rate of risk), dan 3) ketersediaan jumlah dana yang akan diinvestasikan (Halim, 2005: 4). Apabila dana cukup tersedia, biasanya investor menginginkan pengembalian yang maksimal dengan risiko tertentu. Dalam melakukan keputusan investasi, khususnya pada sekuritas saham, return yang diperoleh berasal dari dua sumber, yaitu dividen dan capital gain, sedangkan risiko investasi saham tercermin pada variabilitas pendapatan (return saham) yang diperoleh.

Bisnis adalah keberanian mengambil risiko, sebab risiko selalu terdapat dalam aktifitas ekonomi. Dilema ini bahkan telah melahirkan semacam kaidah umum bisnis; no risk no return. Dengan demikian, persoalan mendasar yang akan dihadapi dalam upaya mewujudkan Islamic ethical investments (pada financial asset) adalah masalah spekulasi terhadap risiko. Bila risiko secara sederhana disamakan dengan ketidakpastian (uncertainty), dan ketidakpastian ini dianggap gharar, sehingga diharamkan, maka permasalahan ini akan menjadi semakin sulit untuk diuraikan. 
Sebelum memecahkan persoalan tersebut, pembahasan tentang risiko perlu ditegaskan terlebih dahulu. Pembicaraan tentang risiko (risk) dalam hal ini harus dibedakan dengan ketidakpastian (uncertainty). Keduanya merupakan istilah yang "serupa tetapi tidak sama." Keserupaan keduanya terletak pada pengertian mengenai adanya suatu kejadian yang belum pasti di masa yang akan datang. Dalam istilah uncertainty, ketidakpastian itu merujuk pada kejadian-kejadian yang tidak diharapkan yang tidak diperkirakan (unexpected risk), sedangkan risiko dalam hal ini dimaksudkan sebagai sesuatu yang dapat diperkirakan (expected risk).

Selanjutnya, perbedaan penting keduanya terletak pada estimasi atas ketidakpastian tersebut. Unexpected risk dalam uncertainty kemungkinan munculnya lebih dari satu, namun probabilitas kemunculannya tidak dapat diketahui secara kuantitatif (Djohanputro, 2006: 14). Sedangkan dalam risiko, tingkat ketidakpastian itu dapat diukur secara kuantitatif (Djohanputro, 2006: 15). Pengukuran risiko investasi secara kuantitatif dalam hal ini hanya dapat dilakukan dalam kondisi tersedianya informasi. Dengan demikian, perbedaan antara uncertainty dan risk mengerucut pada satu kata kunci, yaitu ketersediaan informasi.

Dalam kajian fikih muamalah, istilah yang digunakan untuk menyebut ketidakpastian adalah gharar dan tadlis. Seperti halnya uncertainty dan risk, penggunaan kedua kata ini juga seringkali dipertukarkan, namun sesungguhnya ada perbedaan mendasar. Keduanya sama-sama dikaitkan dengan kurangnya pengetahuan atau informasi. Dalam gharar kurangnya pengetahuan itu dialami oleh kedua pihak yang berakad, sedangkan dalam tadlis hanya dialami oleh salah satu pihak.

Setiap bentuk transaksi yang mengandung unsur gharar dikategorikan ke dalam akad yang tidak diperbolehkan dalam hukum Islam. Meskipun aspek legal mengenai gharar telah jelas, namun persoalan definisi dan penjabarannya secara tepat masih menimbulkan dilema. Sebagaimana dinyatakan Vogel dan Hayes, para fuqaha sebenarnya masih belum bersepakat mengenai cakupan gharar itu sendiri, seperti halnya mereka masih memperdebatkan tentang makna yang sesungguhnya dari riba (Vogel dan Hayes, 1998: 275). 
Ketidakjelasan terkait dengan objek akad yang menjadi sebab dilarangnya akad menurut para ulama meliputi; 1) jenis, 2) spesifikasi, 3) atribut, 4) kuantitas, 5) esensi, dan 6) waktu penyerahan (al-Ameen: 2130). Dengan kata lain, sejalan dengan Ibn Abidin, gharar dapat didefinisikan sebagai ketidakjelasan wujud fisik dari objek akad (mabi'). Definisi yang lebih aplikatif untuk pembahasan investasi ini dikemukakan oleh Imam Sarkhsi yang menyatakan bahwa gharar adalah sesuatu yang akibatnya tidak dapat diprediksi (Huda dan Mustafa, 2007: 31).

Harus diakui bahwa unsur ketidakpastian hampir tidak mungkin diprediksi. Namun sebagaimana dikemukakan sebelumnya, dalam bahasa literatur manajemen keuangan, risiko yang tidak dapat diperkirakan sebelumnya (unexpected risk) disebut sebagai ketidakpastian. Jenis risiko inilah yang dimaksudkan sebagai gharar. Sedangkan risiko dalam pasar investasi adalah jenis risiko yang dapat diprediksi.

Berdasarkan kecenderungan para investor, perilaku preferensi investor terhadap risiko secara garis besar dikategorikan menjadi tiga model (Sundjaja dan Barlian, 2002: 48):

1. Risk seeking, yaitu mereka yang berani mengambil risiko tinggi dengan harapan imbal hasil yang juga relatif tinggi high risk high return.

2. Risk indifferent, yaitu mereka yang cukup berani mengambil risiko yang moderat dengan imbal hasil yang moderat juga (medium risk medium return).

3. Risk averse, yaitu mereka yang hanya berani mengambil risiko dalam tingkat yang relatif rendah dengan imbal hasil yang juga relatif rendah.

Kategorisasi tersebut dapat dijelaskan dengan ungkapan lain bahwa investor ada yang memiliki sikap tidak menyukai risiko (risk averse), bersikap netral (risk indifferent atau risk neutral), dan yang suka mengambil risiko (risk seeker). Berdasarkan tujuan dasar investasi, sesungguhnya semua investor bersikap risk averse, sebab tidak ada seorangpun yang suka menerima risiko. Dengan demikian, asumsi dasar ini mengisyaratkan adanya perbedaan antara investor dengan maysir atau gambler. Ketiga kecenderungan investor tersebut akan lebih mudah dipahami dari tabel berikut: 
Gambar 1:

Jenis Preferensi Risiko

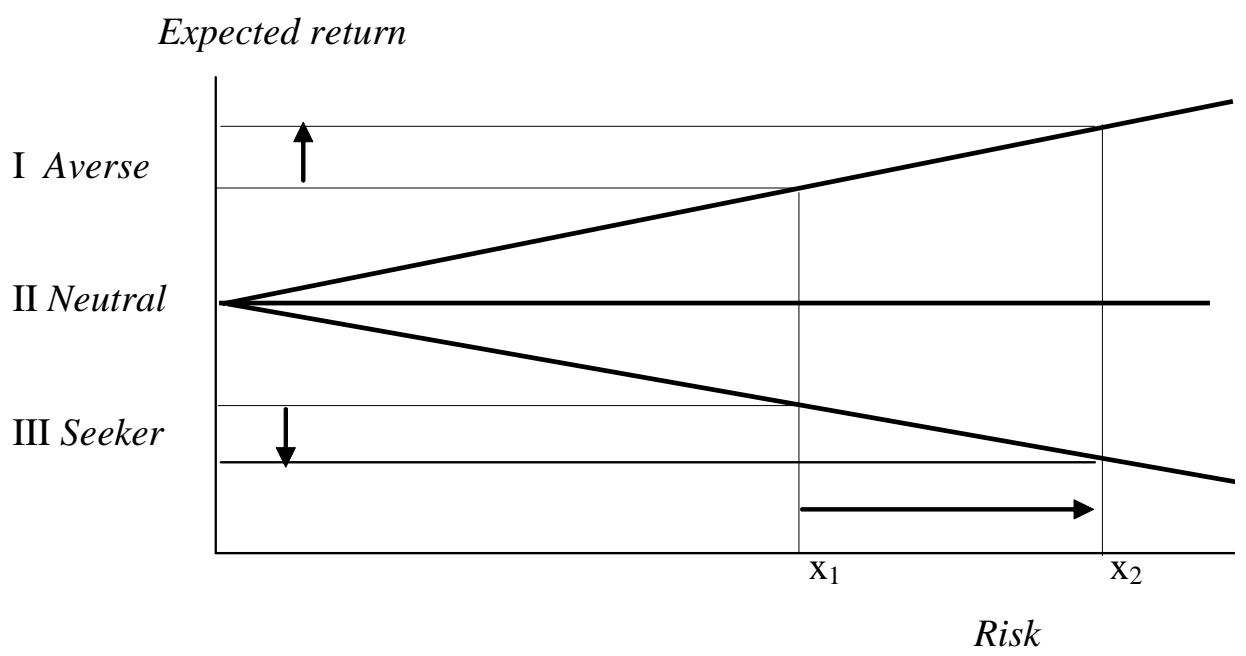

Sumber: Ridwan dan Inge (2002)

Jika risiko bergerak dari $\mathrm{x}_{1}$ ke $\mathrm{x}_{2}$ maka:

1. Bagi investor yang cenderung mengabaikan risiko (risk neutral) maka tingkat return yang diharapkan tidak berubah, artinya tidak adanya perubahan dalam tingkat pengembalian yang diperlukan untuk peningkatan risiko.

2. Bagi investor yang cenderung menghindari risiko (risk averse) penghasilan yang meningkat diperlukan untuk peningkatan dalam risiko. Investor ini mengharapkan pengembalian yang lebih tinggi sebagai kompensasi bagi pengambilan risiko yang lebih besar.

3. Bagi investor yang cenderung menyukai risiko (risk seeker) bersedia penghasilannya berkurang untuk peningkatan risiko. Secara teoritis mereka cenderung menyukai risiko demi penghasilan tertentu (yang lebih banyak).

Idealnya, seorang investor adalah risk averse. Pada umumnya, mereka lebih memilih melakukan diversifikasi dalam investasinya guna mengurangi (menyebar) sebagian risiko yang harus ditanggungnya. Karena risiko tidak sistematis dapat dihilangkan dengan diversifikasi, maka risiko sistematis (beta) menjadi lebih relevan bagi investor. 
Gambar 2:

Risiko Sistematis dan Tidak Sistematis

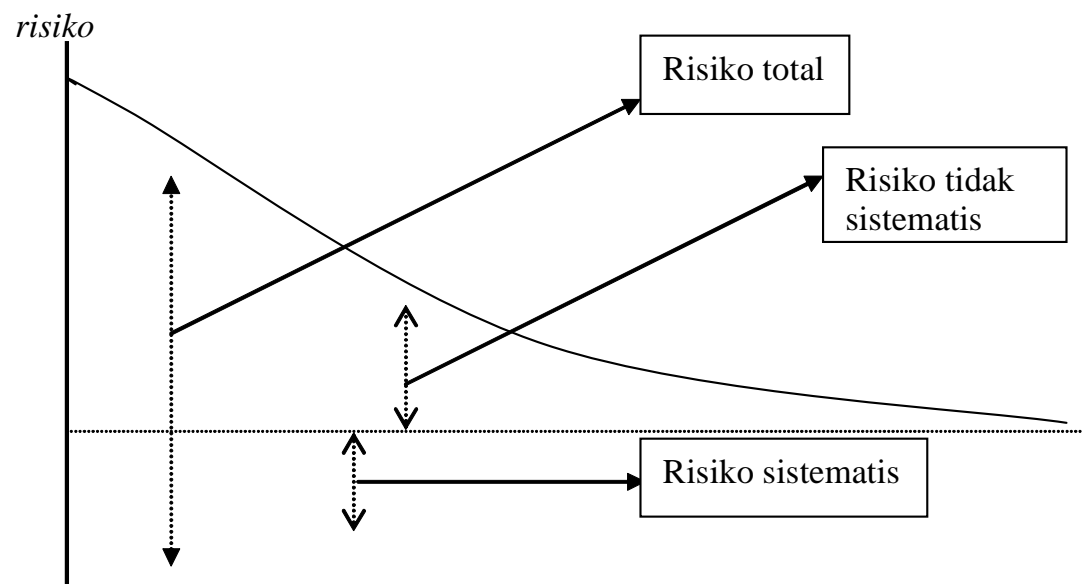

Jumlah saham

Sumber: disesuaikan dari Abdul Halim (2005)

Investor berbeda dengan kreditor dan spekulan atau gambler. Perbedaan mendasar antara investasi dengan lainnya bukan pada bentuknya namun terletak pada "spirit" yang menjiwainya. Para investor membeli sekuritas dengan tujuan untuk berpartisipasi langsung dalam kegiatan bisnis, dengan demikian mereka berperan langsung dalam kegiatan bisnis dan juga menghadapi kemungkinan merugi (risiko). Sedangkan dalam transaksi kredit, seseorang meminjamkan dananya, dan kemudian akan mendapatkan pengembalian dana ditambah dengan bunga yang telah ditetapkan. Transaksi ini mengisyaratkan adanya perolehan keuntungan di atas kerja orang lain (pelaku sendiri tidak bekerja), sehingga dapat dikategorikan mengandung riba.

Demikian juga yang terjadi dalam transaksi spekulasi dan judi, mereka bahkan memperoleh keuntungan tanpa memberikan kontribusi riil dalam perekonomian, bahkan menciptakan penyakit sosial dan merusak tatanan sosio-ekonomik. Pengharaman dan kecaman terhadap praktek spekulasi dan perjudian telah secara tegas ditetapkan dalam Q.S. al-Maidah: 90 dan alBaqarah: 219. 


\section{Analisis Investasi: Pertimbangan Risiko dan Return}

Pendekatan yang biasanya digunakan dalam analisis investasi adalah pendekatan fundamental dan teknikal (Halim, 2005: 5). Pendekatan fundamental didasarkan pada informasi-informasi yang diterbitkan oleh emiten maupun oleh administrator bursa efek. Karena kinerja emiten dipengaruhi oleh kondisi sektor industri di mana perusahaan tersebut berada dan kondisi perekonomian secara makro, maka untuk memperkirakan prospek harga sahamnya di masa mendatang harus dikaitkan dengan faktor-faktor fundamental yang mempengaruhinya. Dengan demikian, analisis ini dimulai dari siklus usaha perusahaan secara umum, kemudian ke sektor industrinya, dan akhirnya dilakukan evaluasi terhadap kinerjanya dan saham yang diterbitkannya.

\section{Analisis Fundamental}

Analisis ini berpegang pada prinsip bahwa saham memiliki nilai intrinsik (nilai yang seharusnya) tertentu. Analisis ini membandingkan antara nilai instrinsik suatu saham dengan harga pasarnya guna menentukan apakah harga pasar saham tersebut telah mencerminkan nilai intrinsiknya atau belum (Halim, 2005: 21). Dengan demikian, ide dasar pendekatan ini adalah bahwa harga saham akan dipengaruhi oleh kinerja perusahaan. Kinerja perusahaan itu sendiri dipengaruhi oleh kondisi perekonomian secara makro.

Penilaian terhadap risiko dapat dilihat dari sudut perilaku dengan menggunakan analisa sensitivitas dan distribusi kemungkinan. Pendekatan ini dapat menentukan tingkat risiko dari suatu aktiva tertentu.

a) Analisa sensitivitas (sensitivity analysis)

Suatu pendekatan perilaku yang menggunakan beberapa kemungkinan taksiran pendapatan untuk mengetahui variabilitas hasil. Pada umumnya, metode yang digunakan dalam mengestimasi tingkat pengembalian dari aktiva adalah sebagai berikut (Sundjaja dan Barlian, 2002: 50):

1. The Pesimistic (pesimistik)

2. The Most Likely (hampir pasti)

3. The Optimistic (optimistik) 
Risiko diukur dengan sebaran, yaitu dengan mengurangi hasil optimistik dengan pesimistik. Semakin besar sebaran aktiva tertentu, semakin banyak variabilitas atau semakin tinggi risiko. Walaupun bagi pengambil keputusan, penggunaan "analisa sensitivitas dan sebaran" sebenarnya merupakan cara "kasar" namun harus diakui metode ini dapat membantu meraba perilaku pengembalian yang dapat digunakan sebagai pertimbangan untuk menilai risiko yang ada.

b) Distribusi probabilitas

Suatu model yang menghubungkan berbagai probabilitas terhadap masing-masing hasil. Probabilitas hasil adalah kesempatan terjadinya hasil tertentu.

Pada pendahuluan telah disampaikan bahwa hubungan antara risiko (risk) dan tingkat pengembalian yang diharapkan (expected rate of return) bersifat linier. Dengan kata lain, risiko bisa didefinisikan sebagai kemungkinan penyimpangan dari hasil yang diharapkan (Muhammad, 2004: 119). Dalam hal ini, penghitungan penyimpangan dapat menggunakan standar deviasi.

Pengembalian (return) secara umum dipahami sebagai total keuntungan atau kerugian yang dialami oleh investor dalam suatu periode tertentu yang dihitung dengan membagi perubahan nilai aktiva ditambah pembagian hasil dalam periode tersebut dengan nilai investasi awal periode (Sundjaja dan Barlian, 2002: 47). Dengan kata lain, return merupakan perubahan nilai atas pengeluaran investasi yang dinyatakan dengan prosentase dari nilai investasi pada periode awal.

Formula yang lebih umum untuk merumuskan return adalah (Muhammad, 2004: 118):

$$
\text { Return }=\frac{\mathrm{P}_{\mathrm{t}}-\mathrm{P}_{\mathrm{t}-1}+\mathrm{D}_{\mathrm{t}}}{\mathrm{P}_{\mathrm{t}-1}} \times 100 \%
$$

Di mana:

$\mathrm{P}_{\mathrm{t}}=$ Harga atau nilai pada periode $\mathrm{t}$

$\mathrm{P}_{\mathrm{t}-1}=$ Harga atau nilai pada periode sebelumnya $(\mathrm{t}-1)$

$\mathrm{D}_{\mathrm{t}}=$ Dividen yang dibayarkan pada periode $\mathrm{t}$ 
Tingkat pengembalian (return) mencerminkan pengaruh gabungan dari perubahan nilai $\left(\mathrm{P}_{\mathrm{t}}-\mathrm{P}_{\mathrm{t}-1}\right)$ dan dividen yang direalisasi selama periode (t). Rumus tersebut digunakan untuk menentukan tingkat return selama periode singkat seperti satu hari maupun jangka panjang seperti sepuluh tahun atau lebih. Dalam banyak contoh (t) adalah sama dengan 1 tahun dan return menunjukkan tingkat pengembalian tahunan.

\section{Analisis Teknikal}

Analisis ini dimulai dengan cara memperhatikan perubahan harga saham itu sendiri dari waktu ke waktu. Analisis ini beranggapan bahwa harga suatu saham akan ditentukan oleh penawaran dan permintaan terhadap saham tersebut. Sehingga asumsi dasar yang berlaku dalam analisis ini menurut Halim (2005: 29) adalah:

1) Harga pasar saham ditentukan oleh interaksi penawaran dan permintaan

2) Penawaran dan permintaan itu sendiri dipengaruhi oleh banyak faktor, baik yang rasional maupun irrasional.

3) Perubahan harga saham cenderung bergerak mengikuti tren tertentu.

4) Tren tersebut dapat berubah sesuai dengan pergeseran penawaran dan permintaan

5) Pergeseran penawaran dan permintaan dapat dideteksi dengan mempelajari perilaku pasar

6) Pola-pola tertentu yang terjadi pada masa lalu akan terulang kembali di masa mendatang.

Beberapa teori yang digunakan untuk mengamati tren yang tengah berlangsung di pasar saham antara lain adalah teori Dow, analisis keluasan pasar, penggunaan grafik batang, analisis kekuatan relatif, dan analisis ratarata bergerak.

Berdasarkan teori Dow, pergeseran harga saham dikategorikan berdasarkan pergerakan pertama (primary movement) yang menunjukkan tren jangka panjang; pergerakan kedua (secondary movement), yang menunjukkan tren beberapa bulan saja; dan pergerakan ketiga (tertiary movement), yang menunjukkan fluktuasi harian. Selanjutnya analisis keluasan 
pasar dilakukan dengan cara membandingkan jumlah saham yang mengalami kenaikan harga dengan jumlah saham yang mengalami penurunan harga lalu diakumulasikan (Halim, 2005: 15).

Selanjutnya, analisis grafik batang dimaksudkan pengamatan pasar saham menggunakan tiga tipe dasar diagram yaitu diagram garis, diagram batang dan diagram gambar titik. Berdasarkan visualisasi grafik batang (bar chart) yang menunjukkan volume saham yang diperdagangkan pada masingmasing perubahan harga, diharapkan dapat menemukan pola-pola tertentu yang berguna untuk prediksi saham dan kondisi pasar (Halim, 2005: 20).

Analisis kekuatan relatif berupaya mengidentifikasikan saham yang memiliki kekuatan relatif terhadap saham lain. Harga saham yang memiliki kekuatan relatif akan meningkat lebih cepat dari harga saham lain pada saat bull market. Dengan memilih saham seperti ini seorang investor akan memperoleh tingkat pengembalian tertinggi.

Sedangkan analisis rata-rata bergerak menfokuskan pada harga ratarata bergerak dengan cara mengamati berbagai perubahan harga yang terjadi pada beberapa hari terakhir pada saat penutupan harga. Dalam hal ini, investor dianjurkan untuk membeli atau menjual saham pada saat yang tepat sesuai dengan informasi garis rata-rata bergerak (moving average).

Secara umum terlihat bahwa berbagai model analisis teknikal di atas dibangun berdasarkan prinsip profit oriented, bahwa saham merupakan suatu komoditas yang harus dibeli atau dijual kembali begitu kondisi pasar tengah kondusif. Dalam perspektif Islamic ethical investment, semangat berinvestasi adalah untuk berperan nyata dalam produksi dengan mempertimbangkan etika (norma-norma agama), bukan sebagai bagian dari game of chance.

\section{Penutup}

Dalam perspektif Islamic ethical investment, tujuan utama dari perilaku investasi adalah memperoleh keuntungan materiil dan spirituil sekaligus. Untuk mencapai tujuan itu, analisis investasi harus mempertimbangkan tingkat pengembalian dan risiko yang mencerminkan kondisi riil, yaitu nilai intrinsik. Untuk mendukung tujuan ini, setiap perusahaan 
emiten harus mengumumkan posisi keuangannya secara rutin sehingga publik akan tahu berapa sesungguhnya nilai intrinsik dari saham-saham yang dikeluarkan.

Selanjutnya, persoalan yang tidak kalah pentingnya terkait dengan kebolehan investasi adalah mengenai tindakan spekulasi terhadap risiko (gharar), sebab transaksi dikatakan gharar risiko, jika yang bakal terjadi tidak dapat diprediksi. Dengan analisis terhadap probabilitas risiko dan expected return, maka seorang investor dapat melakukan prediksi bisnisnya. Inilah yang membedakan investor dengan seorang spekulan maupun gambler.

Terakhir, tulisan ini merekomendasikan agar ketentuan perundangundangan mengenai kegiatan investasi di pasar modal harus dibuat sedemikian rupa sehingga dapat mempersempit ruang gerak bagi tindakan spekulasi. Salah satu implementasi aturan tersebut adalah bagaimana mengatur prosedur pembelian maupun penjualan saham agar tidak terjadi secara langsung.

\section{Daftar Pustaka}

Al-Ameen, Siddiq Mohammad. "Al-Gharar in Contracts and it Effects on Comtemporary Transactions" dalam IRTI: Eminent Scholar's Lectures No.16.

Atta, Hajara. 2000. Ethical Rewards (Dissertation Department of Economics and Finance at University of Durham).

Bakar, Abu dan S.N.Z. Rizal. 2007. "Development of Indonesia's Islamic Capital Market," dalam Islamic Finance News Guide .

Cowton, C.J. 1994. "The Development of Ethical Investment Products," dalam Prindl A.R. dan Prodhan (ed.), Ethical Conflicts in Finance (Oxford: Blackwell).

Djohanputro, Bramantyo 2006. Manajemen Risiko Korporat Terintegrasi, Jakarta: Penerbit PPM

Halim, Abdul. 2005. Analisis Investasi. Jakarta: Penerbit Salemba Empat

Hassan, Abul, Antonios Antoniu dan D. Krishna Paudyal. "Impact of Ethical Screening on Investment Performance: The Case of the Dow Jones and Islamic Index," dalam Islamic Economic Studies Vol. 12, No. $2 \&$ Vol. 13, No. 1 Feb dan Agt 2005. 
Huda, Nurul dan Mustafa E. N. 2007. Investasi pada Pasar Modal Syariah. Jakarta: Kencana

Jones, Charles P. 1996. Investments Analysis and Management. Canada: John Wiley \& Sons, Inc.

Jusmaliani (ed.). 2008. Investasi Syari'ah. Yogyakarta: Kreasi Wacana.

Kuncoro, Y., "Sekarang Waktunya Meraih Pasar Reksadana Syari'ah," The Essays of Yoki. Dalam http://www.mail-archive.com/ekonomisyari' ahy ahoogroups.com/msg00392.html.

Muhammad. 2004. Dasar-Dasar Keuangan Islami. Yogyakarta: Ekonisia

Priyo, Anton. 2008. "Perbandingan Kinerja Reksadana Syari'ah dan Reksadana Konvensional" (Makalah Kelas)

Shaw, William H. dan Vincent Barry. 1995. Moral Issues in Business (USA: International Thomson Publishing.

Sundjaja, Ridwan S. dan Inge Barlian. 2002. Manajemen Keuangan. Jakarta: P.T. Prenhallindo.

Tandelilin, Eduardus. 2001. Analisis Investasi \& Manajemen Portofolio Yogyakarta: BPFE.

Vogel, Frank E. dan Samuel L. Hayes. 1998. Islamic Law and Finance. USA: Kluwer Law International

Wilson, Rodney. "Islamic Finance and Ethical Investment," dalam International Journal of Social Economics. Vol. 24(11). 